\title{
Effects of color in humans generated by led lighting systems
}

\section{Efectos del color en seres humanos generados por sistemas de iluminación led}

\author{
CÓRDOVA-ESCOBEDO, Jesús Fausto †*, MENDOZA-GONZÁLEZ, Felipe, GOMEZ-RODRIGUEZ, \\ Cristian, and CÓRDOVA-MANZO, Jesús Fausto
}

Universidad Veracruzana, Facultad de Ingeniería región Coatzacoalcos-Minatitlán, México.

ID $1^{\text {st }}$ Author: Jesús Fausto, Córdova-Escobedo / ORC ID: 0000-0002-7456-6897, Researcher ID Thomson: S-6737-2018, CVU CONACYT ID: 511561

ID $1^{\text {st }}$ Co-author: Felipe, Mendoza-González / ORC ID: 0000-0003-1172-6782, Researcher ID Thomson: S-6747-2018, CVU CONACYT ID: 947336)

ID $2^{\text {nd }}$ Co-author: Cristian, Gomez-Rodriguez / ORC ID: 0000-0001-9124-6037, Researcher ID Thomson: S-6787-2018, CVU CONACYT ID: 210208

ID $3^{\text {rd }}$ Co-author: Jesús Fausto, Córdova-Manzo / ORC ID: 0000-0001-6284-6990, Researcher ID Thomson: AAV-96022021, CVU CONACYT ID: 1149068

DOI: $10.35429 / \mathrm{JOES} .2021 .25 .8 .1 .12$

Received July 29, 2021; Accepted November 30, 2021

\section{Abstract}

This research evaluates the effects of color in humans generated by LED lighting systems. This evaluation allows us to know the different parameters that these systems generate, such as: the temperature and color of light suitable for human vision and thus be able to implement them in LED lighting designs for work areas. Having an adequate lighting system contributes to visual health and safety by avoiding work accidents. Each color has a different percentage of light reflection and in the same way each color affects us optically and psychologically by causing different sensations and perceptions in human beings such as visual fatigue, exhaustion, eye disorders, lacrimation, irritation, stress, migraines and even impaired vision Taking care of visual health is of vital importance. The methodology for evaluating lighting designs will be with NOM-030-ENER2012. The contribution of this research will be to know the optimal colors and color temperature of light to use in LED lighting systems and to help lighting system designers in the selection of suitable LEDs and area colors that contribute to the visual health of humans

Led lighting design, Visual Health, Color psychology

\begin{abstract}
Resumen
Esta investigación evalúa los efectos del color en seres humanos generados por sistemas de iluminación led. Esta evaluación permite conocer los diferentes parámetros que generan estos sistemas como son: la temperatura y el color de luz adecuados para la visión humana y así poder implementarlos en diseños de iluminación led para las áreas de trabajo. Contar con un adecuado sistema de iluminación contribuye a la salud visual y seguridad al evitar accidentes de trabajo. Cada color tiene diferente porcentaje de reflexión de la luz y de igual manera cada color nos afecta óptica y psicológicamente al provocar diferentes sensaciones y percepciones en los seres humanos como la fatiga visual, agotamiento, trastornos oculares, lagrimeo, irritación, estrés, Jaquecas e incluso visión alterada. Cuidar la salud visual es de vital importancia. La metodología de evaluación de los diseños de iluminación será con la NOM-030-ENER-2012. La contribución de esta investigación será conocer los colores y temperatura del color de la luz óptimos a usar en sistemas de iluminación led y ayudar a los diseñadores de sistemas de iluminación en la selección de leds adecuado y colores del área que contribuyan a la salud visual de los seres humanos
\end{abstract}

Diseño de iluminación led, Salud Visual, Psicología del color

Citation: CÓRDOVA-ESCOBEDO, Jesús Fausto, MENDOZA-GONZÁLEZ, Felipe, GOMEZ-RODRIGUEZ, Cristian, and CÓRDOVA-MANZO, Jesús Fausto. Effects of color in humans generated by led lighting systems. Journal of Experimental Systems. 2021. 8-25: 1-12

\footnotetext{
* Author Correspondence (fcordova@uv.mx).

$\dagger$ Researcher contributing as first author.
} 


\section{Introduction}

During the history of man, he has always tried to illuminate his paths, homes, workplaces to see in the dark. In 1962, Nick Holonyak Jr. developed the first visible light LED and mentioned in 1963 that LED lamps would replace incandescent bulbs, he was not wrong since LEDs have a very important role in the modern world and today they are offered in different ways. powers, sizes and shapes, for example, exist in different emission colors (red, purple, blue, green, yellow, orange) and the most popular white and yellow. Its use has increased due to the low power consumption and its long life in hours of approximately 15,000 hours on average.

Currently when designing lighting systems with LEDs, human sensations and perceptions are not always taken into account, which affect human beings in their visual and psychological health, many times only energy saving, resistance to shocks, lights are considered of colors that can be changed by means of an application or command, among others.

Knowing these effects will allow lighting system designers to select the best light color emission with LEDs, respecting the luxes required according to the NOM for study or work areas, and considering the parameters of color temperature, contrast, color rendering quality, glare, color rendering index, generated shadows (dark region where light is obstructed).

These last parameters are often not considered by designers, for example, the shade is used not only to be able to have rest and a state of relaxation at bedtime, but also to carry out normal human activities
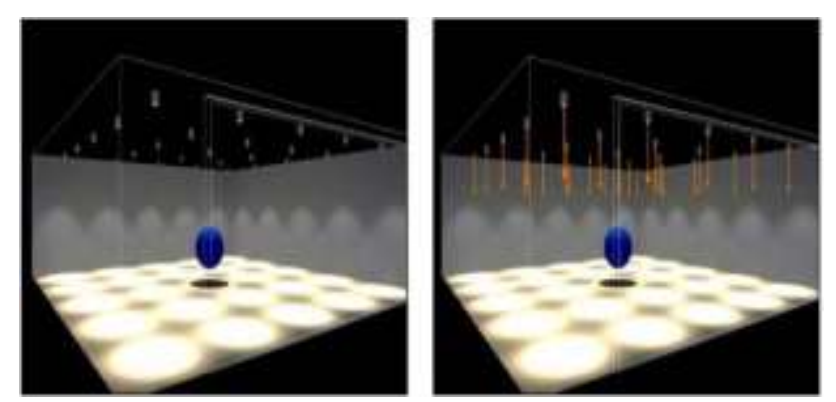

Figure 1 Shadow of a sphere object. White led (left) vs yellow led (right)

Source: Dialux Lighting Manual

\section{Concepts and parameters to consider when designing led lighting}

Contrast refers to the phenomenon with which colors can be differentiated according to the brightness and the background color on which it is projected. For sufficiently high levels of illumination, the normal eye is sensitive to colors, while for low levels of illumination the objects are perceived mainly by the contrast of luminances that they present in relation to the background.

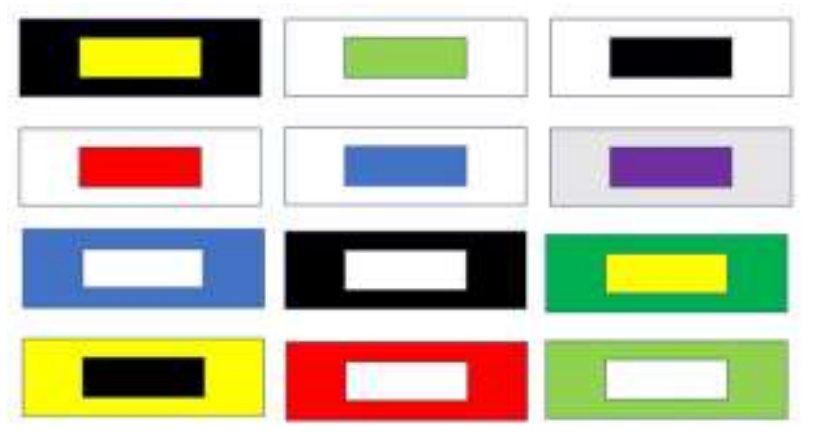

Figure 2 Examples of Contrasts Source: Own, made in Auto CAD

The difference in luminance between the object being observed and its immediate space is what is known by contrast. The correct combination of colors helps to better distinguish the objects that surround us and thus prevent accidents, the NOM-026-STPS-2008 recommends the following for contrasts:

\begin{tabular}{|l|l|}
\hline Safety color & \multicolumn{1}{|c|}{ Contrast color } \\
\hline Red & White \\
\hline Yellow & Black and Magenta \\
\hline Green & White \\
\hline Blue & White \\
\hline \multicolumn{2}{|c|}{ Example Reading on monitors } \\
\hline Black & white \\
\hline
\end{tabular}

Table 1 Selection of contrasting colors Source: Secretary of labor and social security

\section{Color measurement}

The eye is responsible for color vision, within the retina there are receptors called cones that are sensitive to three wavelengths that correspond to the color red, blue and green, for this reason three numerical components are used to quantify the color. For this reason it is called visual trivariate (RGB system). 


\section{Chromatic diagram}

To avoid that the color evaluations are subjective and can be represented mathematically, systems such as Musell, CIE Lba, CIE y, x, z are used. The Commission Internationale de I'Eclairage defines the CIE Chromatic Diagram as a color identifier, which is used to quantitatively treat light sources, colored surfaces, paints, etc. This diagram represents all the colors that the human eye is capable of seeing. In the diagram, all the colors are ordered by three chromatic coordinates $\mathrm{x}, \mathrm{y}, \mathrm{z}$, the sum of which is unity.

This means that by having 2 coordinates a color can be defined and by means of the spectral composition the color of the light is determined by calculation. The chromatic diagram, also known as the CIE chromatic triangle, presents a curved shape in the upper part that is where the monochromatic radiations are found, that curve is closed in the lower part by the purple line, which is a straight line. The central part of the triangle is achromatic and the colors of the artificial light sources are located on it. The center is a white point in which the coordinates are equal to each other of 0.333 .

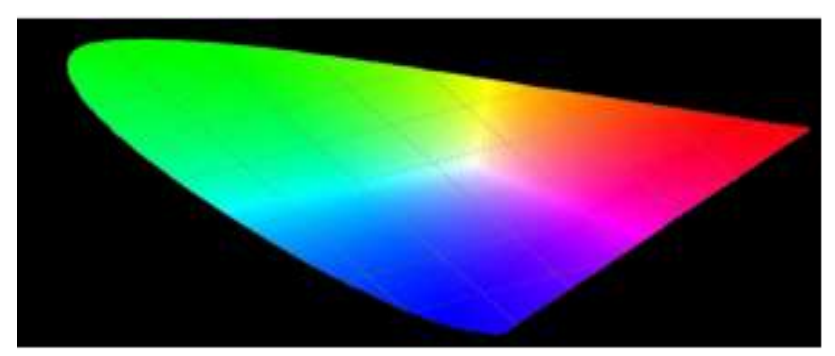

Figure 3 Chromatic diagram

Source: Self Made

\section{The color temperature}

Is used to determine how cold or how warm is the light emitted by each led lamp. This measure has a great impact on the area or space that is illuminated. The magnitude of this measure is directly related to the activity carried out in the space to be illuminated. To determine the color temperature of a light source, it is compared with that of a black body, which emits radiation with a wavelength that depends on its temperature. The tone emitted by the luminaire is compared with the tone that the black body has when raising or lowering the temperature. The temperature is assigned to the luminaire when the black body achieves a tone close to the luminaire. If the temperature is low, the tone of the yellow color intensifies.
When the temperature is increased, the blue color intensifies.

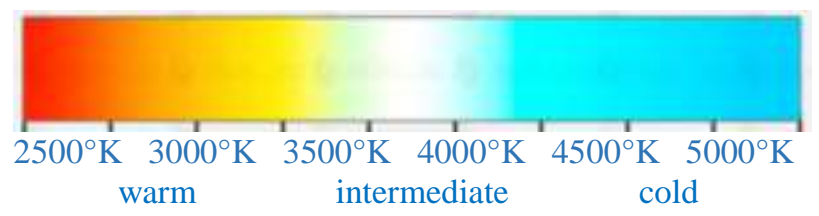

Figure 4 Color temperature Source: Self Made

\section{Color reproduction}

For an object to be appreciated in its entirety, a good color reproduction of said object is needed. The color temperature data refers only to the color of the light, but not to its spectral composition, which is decisive for color reproduction. IRC is defined by its English name Color Rendering Index, as the ability of a source to reproduce the colors of the object it illuminates.

The IRC or RA is independent of the color of the light emitted by the source. A high RA better reproduces the colors of illuminated objects. In order to acquire a good luminaire, you must pay attention to the RA that is indicated on the lamp, which is a numbering that goes after the power, the first digit indicates the IRC, the next two the color temperature. If the number is 870 , the 8 means that the lamp has an RA of 80 , the number 70 is assigned to the color temperature that means that it has $7000^{\circ} \mathrm{K}$. The following table shows the quality of the reproduction of the images. colors:

\begin{tabular}{|l|l|}
\hline \multicolumn{1}{|c|}{ RA } & \multicolumn{1}{c|}{ Calidad } \\
\hline RA $<60$ & Poor \\
\hline $60<$ RA $<90$ & Well \\
\hline $80<$ RA $<90$ & Very good \\
\hline $90<$ RA & Excellent \\
\hline
\end{tabular}

Table 2 Color rendering quality Source: Self Made

\begin{tabular}{|l|r|}
\hline \multicolumn{1}{|c}{ Lamp type RA } & Lamp type RA \\
\hline Incandescent lamps & 100 \\
\hline Standard fluorescent lamps & 60 \\
\hline Special fluorescent lamps & 94 \\
\hline Mercury Vapor Lamps & $35-50$ \\
\hline Low pressure sodium vapor lamps & 20 \\
\hline led lamps & $80-95$ \\
\hline
\end{tabular}

Table 3 RA for each type of lamp Source: Self Made 


\section{Appreciation of objects}

Through the contraction of the ciliary muscles, the convexity of the lens of the eye is increased in order to focus on distant or near objects. The process called accommodation (changes in the diameter of the pupil) helps visual focus on the object. When the eye is focused on nearby objects, the pupil contracts slightly and allows less light to enter the eye. On the other hand, when the eye is focused on distant objects, the pupil expands allowing more light to enter. Changes in pupil size are due to three types of reflections: the light reflection, the closeness reflex, and the psycho-sensory reflex.

The light reflection occurs when lighting changes in the environment and the psychosensory reflex consists of a pupillary dilation associated with a relevant task or stimulus presented in any sensory modality. In this case the changes in pupil size are more subtle and are mediated by the sympathetic nervous system and are not due to the physical properties of the stimulus but to the cognitive and emotional involvement of the processing. (Duque \& Vázquez, 2013).

If the eye works with good lighting, the eye has greater sensitivity at the wavelength of $555 \mathrm{~nm}$ in which the greenish-yellow color is found and the minimum of the red and violet colors. The visual field of the human eye is 130 ${ }^{\circ}$ vertical and $180^{\circ}$ horizontal, outside of these angles, the eye does not see any object.

\section{Colors in health}

Colors influence our thoughts, emotions and our health. (Graham, 2002). Graham also states in his book, that there have been several studies of the behavior of color in health, one of them is the research of Rudolph Steiner, at the beginning of the 20th century, who related color with figure, shape and sound. He stated that using colors in the correct way, amplifying their color, combination and giving it certain shapes, can become destructive or regenerative for human beings. Today the inspiration of this researcher reaches schools where they are painted and textured according to the stage of development in which the students are.

Researcher Max Lüscher, who was a professor of psychology at the University of Basle, claimed that color shows the state of mind with a physical and psychological diagnosis.
Researcher Robert Gerard proposed that the color red generated anxiety or tension for some people, on the other hand the blue color had a calming effect. Gerald suggested that psychophysiological activation increases with the variation of colors ranging from blue to red, this statement is directly related to the color temperature mentioned here. Gerald, said that blue helped in the treatment of various diseases, as it had therapeutic benefits. He pointed out a clear example such as support for anxious people and support for lowering blood pressure for people with hypertension treatments.

\section{Healing Colors}

In 1990, scientists reported at the annual conference of the American Association for the Advancement of Science on the successful use of blue light in the treatment of a wide variety of psychological problems, including addictions, eating disorders, impotence and depression.

Traditional medicine (magic) was used for the same purpose. For example, people with rashes wore red rose petals, those with fever, epilepsy, scarlet fever, and inflammations were dressed in red or had red necklaces. Some of these cases were cured due to the psychological effect produced by beliefs about colors, causing a placebo effect. Another example is:

\section{Pictorial therapy}

Considered effective, consists of patients painting situations in their lives with colors that are their favorites or those that they like. With this therapy they help patients to express their feelings through colors and improve their mood.

\section{Glare}

According to the Official Mexican Standard NOM-025-STPS-2018 is any glare that causes discomfort and causes interference to vision or visual fatigue. This phenomenon acts on the retina of the eye and produces instability in vision for a short time, after which vision is restored. There are two types of glare, the direct ones, caused by looking directly at the light source: It is the most irritating; as it results in fatigue and reduces perception. The Reflected: It is produced by the incidence of light rays on the object that is observed, such as a metal. If the phenomenon is very prolonged, loss of contrast and visual fatigue occur. 


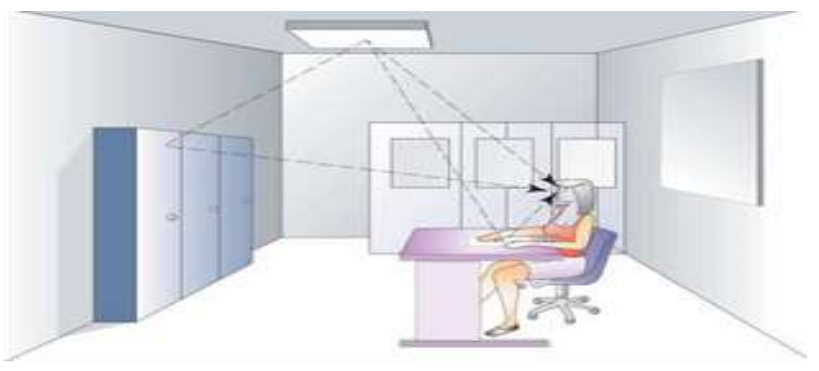

Figure 5 Surfaces causing glare

Source: Luminotecnia. https://rua.ua.es/dspace/pdf

\section{Magnitudes and units of measurement}

In lighting technology, magnitudes are used to quantitatively represent the properties of light sources, or the light effects they cause.

\section{Luminous flux}

It is the energy of light emitted in all directions by a light source or luminaire per unit of time. Its unit of measurement is the Lumen $(\mathrm{lm})$ and it is represented by the Greek letter $\Phi$. A test is to take two luminaires of different powers, so we could observe that, having different powers, the one with the highest power will provide more light.

\begin{tabular}{|lr|r|}
\hline Type of lamps & Power & \multicolumn{1}{c|}{ Lm } \\
\hline Incandescent & $60 \mathrm{~W}$ & 730 \\
\hline Halogen & $1,000 \mathrm{~W}$ & 22,000 \\
\hline sodium vapor & $1.000 \mathrm{~W}$ & 120,000 \\
\hline Mercury Vapor & $125 \mathrm{~W}$ & 5,600 \\
\hline Fluorescent & $65 \mathrm{~W}$ & 5.100 \\
\hline Led & $60 \mathrm{~W}$ & $\mathbf{8 , 5 0 0}$ \\
\hline
\end{tabular}

Table 4 Lumens generated by luminaires Source: Self Made

\section{Luminance}

It is the amount of light emitted in a given direction by a luminous or illuminated surface. Its unit of measurement is the candela per surface

\section{Reflection}

It is a luminous phenomenon that occurs when a ray of light hits an opaque surface and cannot penetrate, therefore, the ray of light bounces. When light is reflected by a surface, a percentage of that light is lost due to the absorption phenomenon. The relationship between the reflected light and the incident light is called surface reflectance and the surface color is fundamental, for light tones there is greater reflection, for dark tones, there is greater absorption.

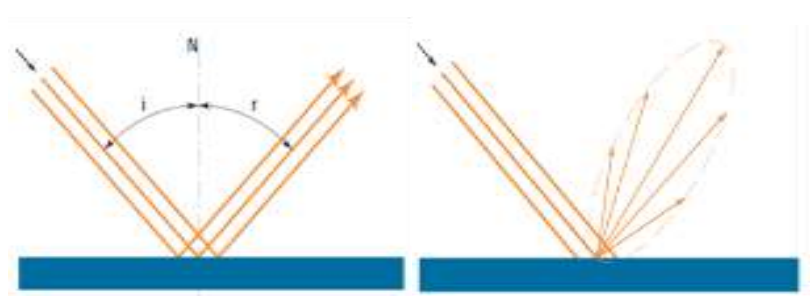

Figure 6 Specular Reflection and Composite Reflection Source: Luminotecnia. Electrosertec
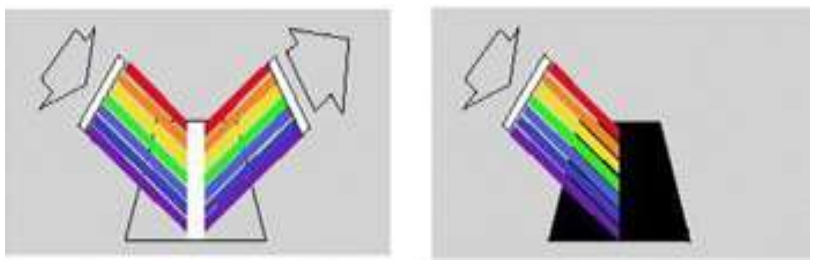

Figure 7 Light absorption

Source: Lighting Manual. https://electrosertec.com

\section{Color psychology}

Throughout our lives we live with color, it gives life to objects and our reality. Color in human psychology is the psychoanalysis's term for desires, impulses, and demands. Color has such an influence on human behavior that color speaks to our senses, making us feel different emotions or moods. The effects of color on people range from physiological to psychological, producing different sensations and emotions, therefore, it has different perceptions in each person. Color is capable of motivating or containing, it can create happiness or depression. In the physical it is known that it can produce thermal sensations, they can make us feel hot or cold. Throughout history, the human being has assigned emotional or symbolic meaning to each of the colors. Each of these depend on the time and culture, it is difficult to understand outside the context in which they were given. The attributions of colors are not only studied by artists, but also by doctors, scientists, politicians, communicators, etc. (Fuentes, 2015).

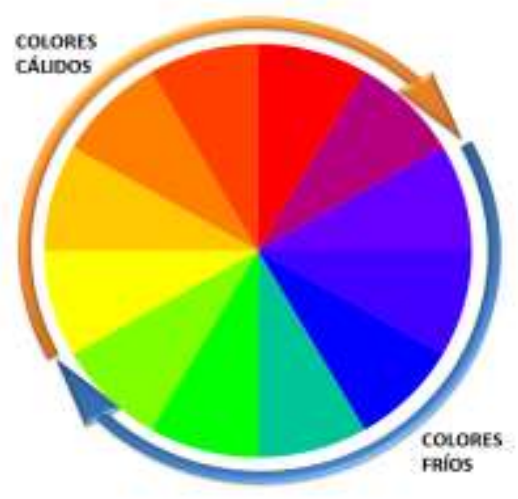

Figure 8 Warm and cold colors

Source: http://profedavidduarte.blogspot.com

CÓRDOVA-ESCOBEDO, Jesús Fausto, MENDOZA-GONZÁLEZ, Felipe, GOMEZ-RODRIGUEZ, Cristian, and CÓRDOVA-MANZO, Jesús Fausto. Effects of color in humans generated by led lighting systems. Journal of Experimental Systems. 2021 
Hot and cold colors are named because of their position in the electromagnetic spectrum. The warm colors are those which correspond to the long waves, with respect to the cold colors, they are in the short waves. Researcher Robert Gerard proposed that the color red generated anxiety or tension for some people, whereas the color blue had a calming effect. Gerald suggested that psychophysiological activation increases with the variation of colors ranging from blue to red (Graham, 2002).

In the world of work, the use of color in machinery, in work areas, in uniforms, can influence the performance of workers, their safety and their emotional state. The recommended colors for machines that must be worked with during a long day are cold and pale, because they do not disturb visually.

Next, it is shown what each color generates in the human being. (Varley, 1982).

Red: The color red symbolizes energy and heat in psychology, it awakens emotions, such as passion and strength. In bright and strong tones, it symbolizes anger, blood, fire and sex. It is used to mark danger zones, giving a meaning of urgency and importance.

Blue: The color blue represents in psychology the opposite of red, while one represents energy, blue represents calm, purity, it can induce sleep. It can be used to symbolize trust, respect, formality.

Yellow: This color symbolizes energy, kindness, warmth and is characterized by its luminosity. It is used to represent light, the sun, nature and for prevention notices. The yellow ones represent intelligence, it is used in children with learning difficulties and in patients who present anger.

Green: Green refers to nature and harmony, representing freshness and tranquility. In medicine it is associated with the locomotor system, due to its intensity it can be used in hospitals, in luxury, quality and extravagance cases.

Orange: This color represents balance, grace, warmth, fun, and vibrancy. It is associated with vitality. It is used in restaurants. It is best used in small items, as it can cause fatigue when used in large quantities.
Violet: It is related to the nervous system, with it you can treat restlessness, anxiety, tumors, as well as menopause. It is related to mysticism and spirituality. It was used to represent luxury, royalty, femininity, and romanticism.

Brown: This color is associated with tranquility and comfort, it is often used to represent good health. It is used to represent wood, earth, autumn, the rustic.

Black and white: Opposite colors, representing darkness and light respectively. White is synonymous with purity, cleanliness, while black represents sadness, unhappiness. They are colors that when combined with others change their characteristics or representations, for example, the combination with the color red, can make it look like a warm or cold color depending on the mixture. The mixture of both results in the gray color, which represents good taste and is very conservative. When mixed with the black color it can appear vitality.

\section{Methodology}

To evaluate the effects generated by LED lighting systems, the Official Mexican Standard (NOM) was taken as a basis. for this case:

NOM-025-STPS-2008: Lighting
conditions in work centers.

NOM-007-ENER-2014, Energy efficiency in lighting systems in buildings.

NOM-030-ENER-2016, Luminous efficacy of integrated light-emitting diode (led) lamps for general lighting. Limits and testing methods.

NOM-031-ENER-2012, Energy efficiency for luminaires with light-emitting diodes (LEDs) for roads and public outdoor areas. Specifications and test methods.

It was also used:

a. the lumens method

b. the point-by-point method

c. the dialux software, which allows the simulation and design of LED lighting systems.

d. the POV Raytracer program, which helps to render 3D images. 
e. A lux meter for lux measurements.

f. A smartphone with the lux meter App to measure lux

The dialux software is evaluated and endorsed software that allows you to create professional lighting projects for interiors and exteriors, respecting the NOM standard. This software has an updated database of various luminaires from various manufacturers in the world.

\section{Phase 1. Data analysis}

To determine the effects that led lighting systems generate in humans, a new project will be designed, evaluated and simulated based on a multipurpose academic classroom at the Universidad Veracruzana, Coatzacoalcos campus of the Faculty of Engineering, with the following required measurements and parameters:

- Multipurpose classroom

- Length: $20 \mathrm{~m}$

- Width: 15

- Height: $3.5 \mathrm{~m}$.

- Maintenance plan

- Degradation factor 0.80

Degrees of reflection:

- Soil $80 \%$

- Wall $80 \%$

- Roof $50 \%$

- Illumination level

- 300 lux.

- Type of Luminaire

- 2600lm 86W luminous flux led,

- Led with luminous flux $5600 \mathrm{~lm}$ of 70W

- correction factor 1.

- Color of the LEDs to be used

- White Simulation 1

- Yellow simulation 2

\section{Phase 2 Data entry}

The data entered for the multipurpose classroom simulation project was

Length: $20 \mathrm{~m}$, width: 15, height: $3.5 \mathrm{~m}$.

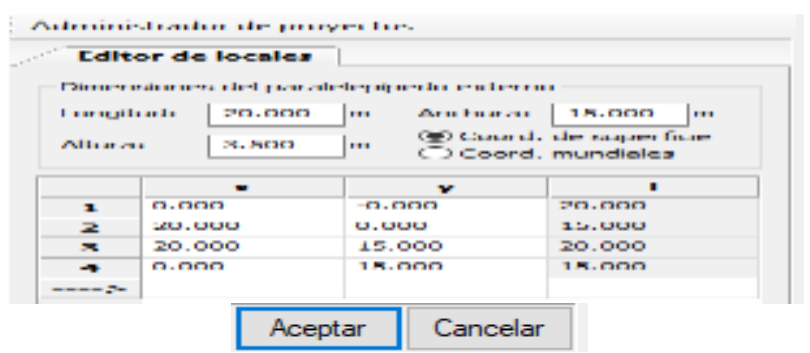

Figure 9 Multiple-use classroom project, data entry. Source: Dialux Software 4.13

Subsequently, the maintenance factor of 0.8 is entered, which means that the lighting is in a clean room.

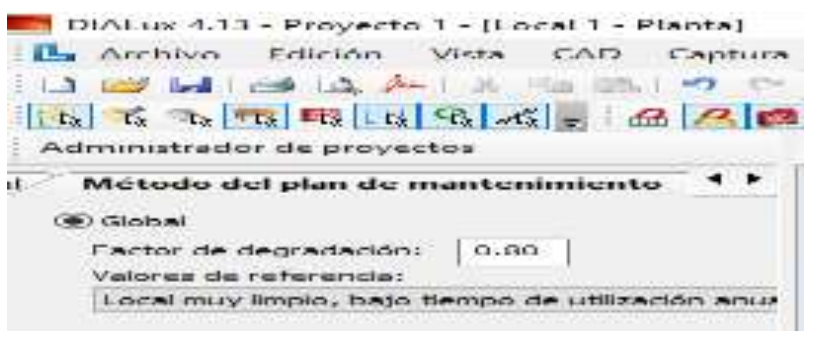

Figure 10 Degradation factor

Source: Obtained from Dialux 4.13

The degree of reflection of the walls, ceiling and floor is entered, they depend on the material with which each of the surfaces and the color. The degrees of reflection that were mentioned will be used.

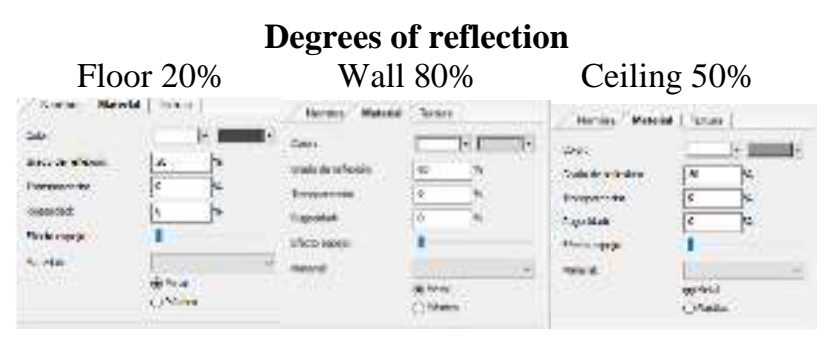

Figure 11 Degrees of reflection

Source: Dialux 4.13

\section{Classroom object simulation}

This simulation allows to determine the possible shadows, contrasts and glare. As the project is a multipurpose classroom with the objects tab, the objects of a classroom with chair, desk, blackboard, windows and doors are placed, where all the objects move and rotate. Colors can be added to all objects. Some texture is added to the doors, walls and windows. 


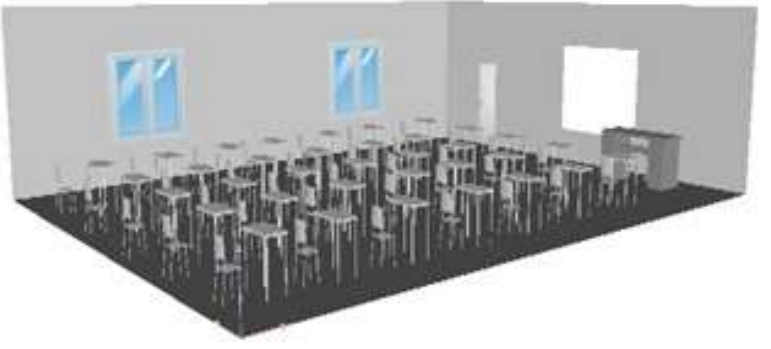

Figure 12 3D view of the multipurpose classroom. Source: Dialux 4.13

\section{Luminaire selection}

Subsequently, the luminaire for the premises is selected. There are various catalogs of luminaires, the software in its database has a great variety of luminaires from various manufacturers. For this project, a 2600 luminous flux led luminaire is used, power $86 \mathrm{~W}$, correction factor 1 , white color.

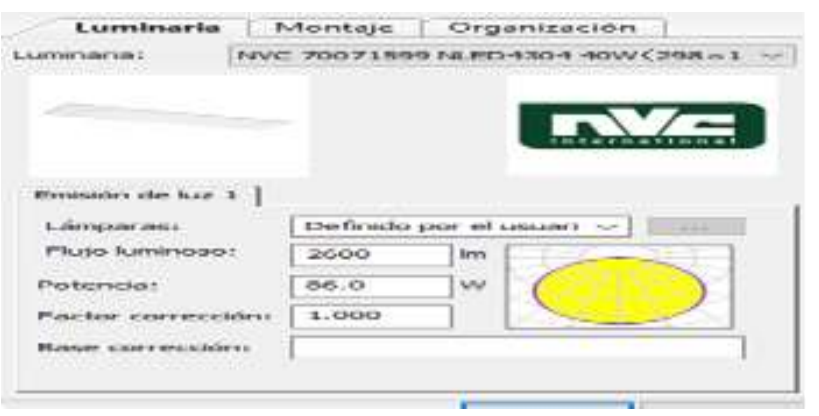

Figure 13 Selected luminaire.

Source: Dialux 4.13

\section{Phase 3 Data processing}

After entering the data, NOM-025-STPS-2008 determines that the value of the average level of illumination required for a classroom is $300 \mathrm{~lx}$ (lux). In the software the average level of illumination required is entered and with this the number of luminaires that are needed to reach the desired level is generated.

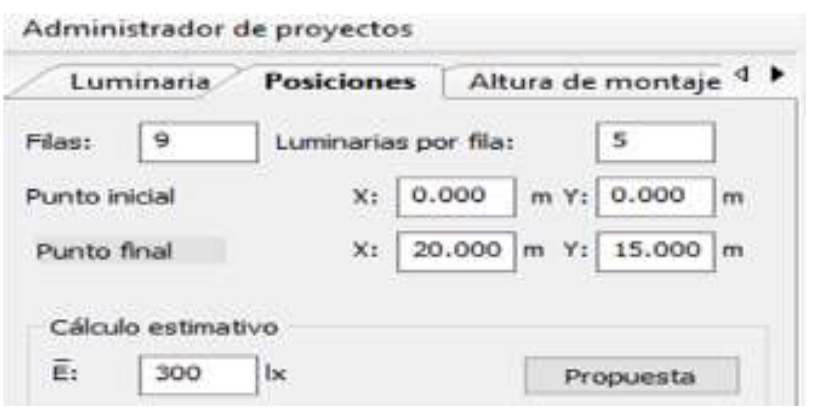

Figure 14 Average illumination level 300 lx. Source: Dialux

\section{Phase 4. Interpretation of the results}

Figure 14 shows the result of 9 rows and 5 columns. This indicates that 45 led luminaires with 2600 luminous flux, power $86 \mathrm{~W}$, correction factor 1 , white color are required to satisfy the requirements of the $300 \mathrm{~lx}$ classroom project. To know the distribution of luminaires, it is calculated by clicking the icon at the top called start calculation.

\section{Phase 5. Validation of the results}

The simulation is validated, because it coincides with the results obtained with the lumens method with the same data entered.However, the lumens method calculates 300 lux, with a 7-row x 6column luminaire distribution variant that results in 42 LED luminaires.Both answers are correct and in this phase, the distribution depends on the designer, in this project is decided by 45 luminaires.

\begin{tabular}{|l|c|c|c|c|}
\hline Surface & $\mathbf{p ~ [ \% ] ~}$ & $\mathbf{E m}[\mathbf{l x}]$ & $\mathbf{E m i n}[\mathbf{l x}]$ & $\mathbf{E m a x}[\mathbf{l x}]$ \\
\hline Useful Plane & $/$ & 309 & 176 & 377 \\
\hline Ground & 20 & 286 & 159 & 349 \\
\hline The ceiling & 80 & 62 & 51 & 96 \\
\hline Walls (4) & 50 & 159 & 65 & 327 \\
\hline \multicolumn{5}{|c|}{ Useful plan } \\
\hline Height & $0.850 \mathrm{~m}$ \\
\hline Plot & $64 \times 64$ points \\
\hline Marginal zone & $0.250 \mathrm{~m}$ \\
\hline
\end{tabular}

Table 5 Simulation results

The following figure shows the Distribution of the 45 lights of the academic classroom project.

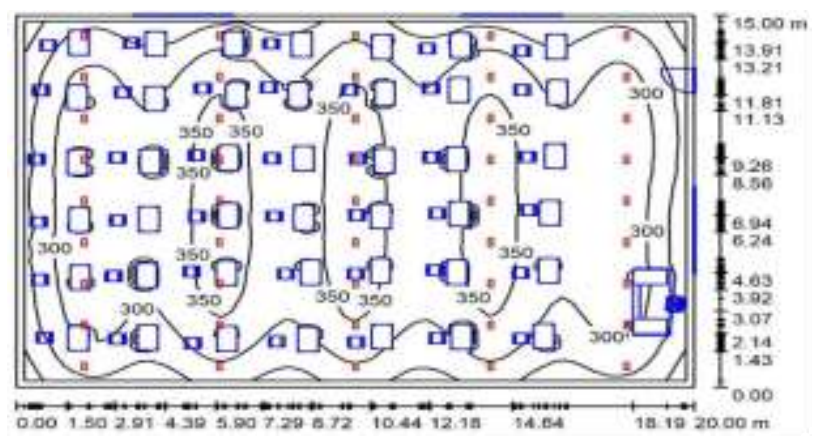

Figure 15 Distribution of the 45 led luminaires and the Isolines generated in the multipurpose classroom. Source: Dialux 4.13

The simulation results are correct and coincide with those calculated by the lumens method, since the average level of illumination is above that required as determined by NOM025-STPS-2008 (2008), which in this case is 300 $1 \mathrm{x}$. Any professional designer of LED lighting systems would validate this proposal.

CÓRDOVA-ESCOBEDO, Jesús Fausto, MENDOZA-GONZÁLEZ, Felipe, GOMEZ-RODRIGUEZ, Cristian, and CÓRDOVA-MANZO, Jesús Fausto. Effects of color in humans generated by led lighting systems. Journal of Experimental Systems. 2021 
However, the goal of the research is to offer designers other options such as using yellow LEDs instead of white LEDs.

\section{Phase 6. Simulations with colors}

Color influences our personal relationships, moods and our perception of the environment. In the same way, the color emitted by the luminaire affects us. The color of the luminaires generates an effect of tranquility, alteration, heat or cold. Simulations are carried out that will demonstrate which color of the luminaires generates better comfort and helps health, for this simulation the same measurements of the Classroom project will be taken: Length: $20 \mathrm{~m}$, Width: $15 \mathrm{~m}$. Height: 3.5 m, 300 lx,

The luminaire selected for the simulation is: $5600 \mathrm{~lm}$ LEDs at $72 \mathrm{~W}$

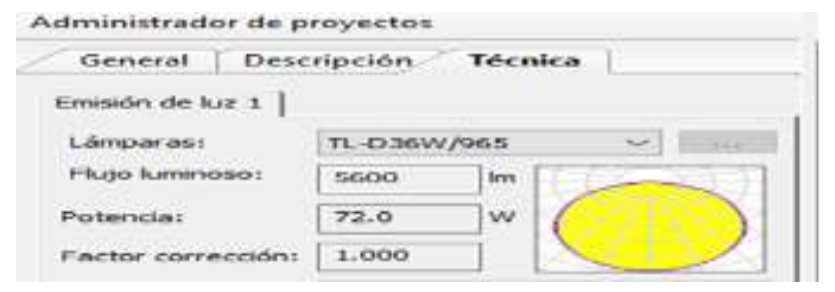

Figure 16 Lamp selection Source: Dialux 4.13

The same procedure of the first simulation will be followed, with its variants such as the type of luminaire. Different simulations were carried out with different proposals, the results of which are shown in the following figures, source Dialux.

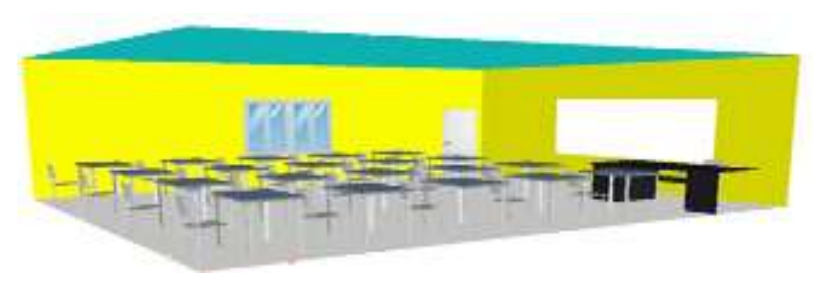

Figure 17 Light colors with yellow light.

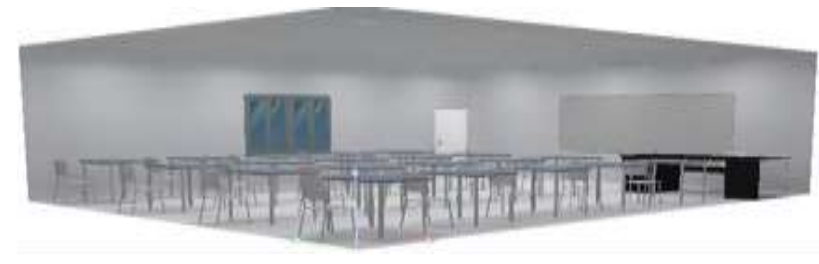

Figure 18 Gray colors with white light

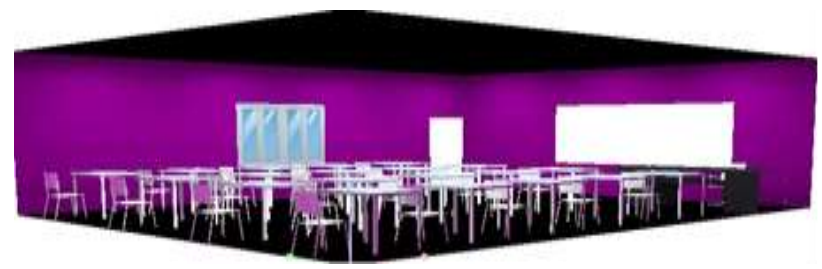

Figure 19 Dark colors with white light.

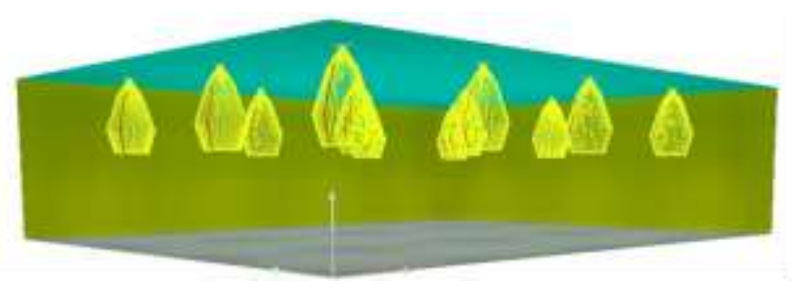

Figure 20 Light colors with yellow light.

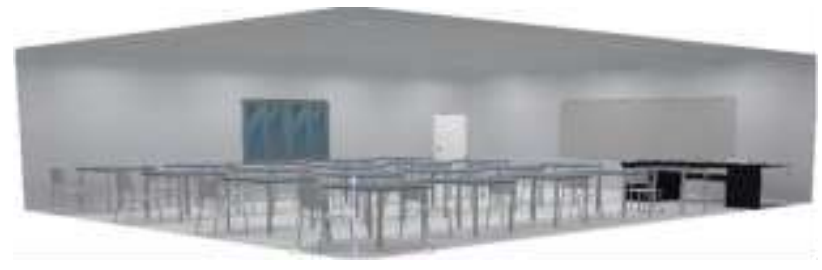

Figure 21 Gray colors with yellow light

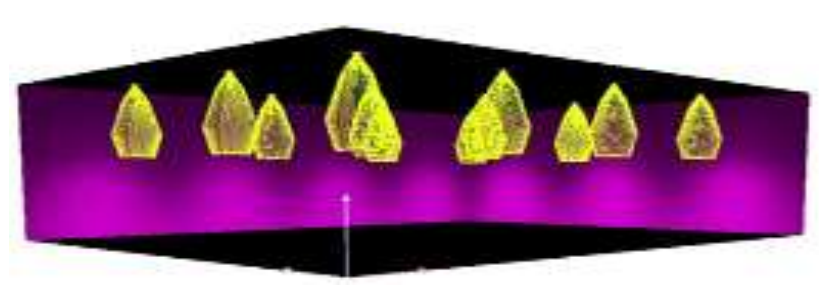

Figure 22 Dark colors with yellow light.

The following table shows the luxes obtained in each simulation grouped by the color of the light.

\begin{tabular}{|c|c|c|c|}
\hline $\begin{array}{c}\text { Type of } \\
\text { light }\end{array}$ & \multicolumn{1}{c}{$\begin{array}{c}\text { Light } \\
\text { colors }\end{array}$} & \multicolumn{1}{c|}{$\begin{array}{c}\text { Gray } \\
\text { colors }\end{array}$} & $\begin{array}{c}\text { Dark } \\
\text { colors }\end{array}$ \\
\hline Yellow & $566 \mathrm{~lx}$ & $449 \mathrm{~lx}$ & $363 \mathrm{~lx}$ \\
\hline White & $467 \mathrm{~lx}$ & $431 \mathrm{~lx}$ & $335 \mathrm{~lx}$ \\
\hline
\end{tabular}

Table 6 Comparison of luxes generated by colors Source: Self Made

\section{Phase 7. Simulations with color temperatures}

The color temperature is modified, for demonstration purposes, luminaires and LEDs are selected with the colorimetric data in which the temperature of the selected luminaire and the spectrum are found. The different color temperatures that were obtained are shown. 


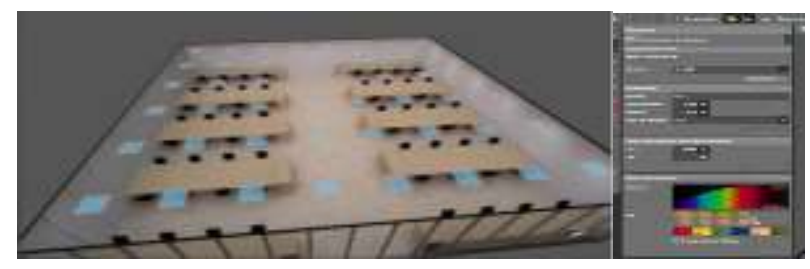

Figure 23 Classroom plan view Source: Dialux evo

The luminaire selected for the first calculation has a temperature of $4000^{\circ} \mathrm{K}$. To appreciate the difference in color temperature, three more color temperatures will be selected

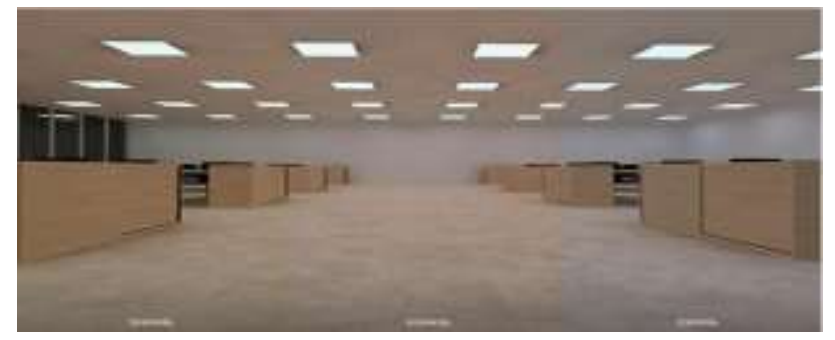

Figure $244000^{\circ} \mathrm{K}$ data.

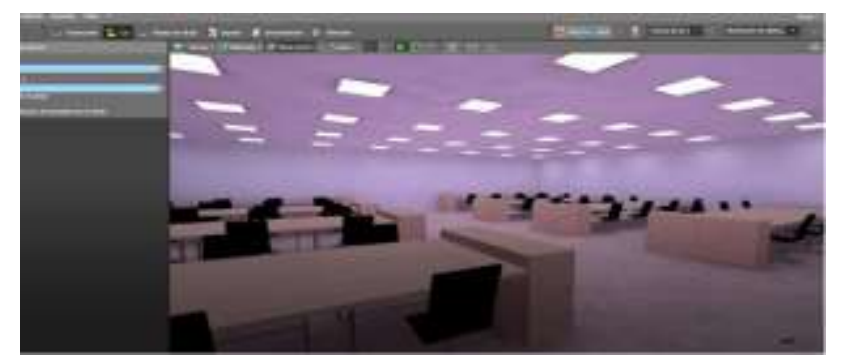

Figure 25 Data $25000{ }^{\circ} \mathrm{K}$

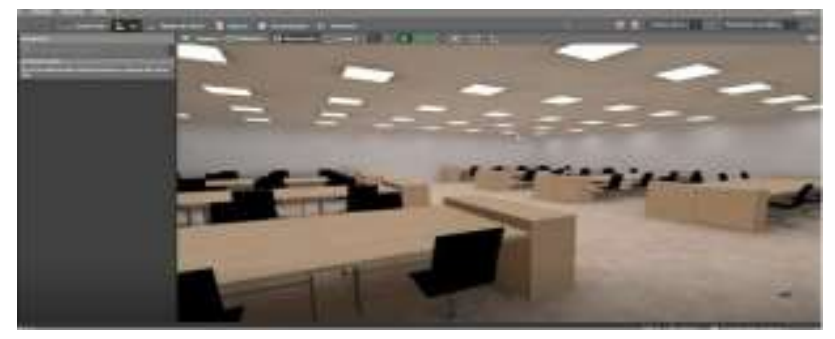

Figure 26 Data $6873^{\circ} \mathrm{K}$

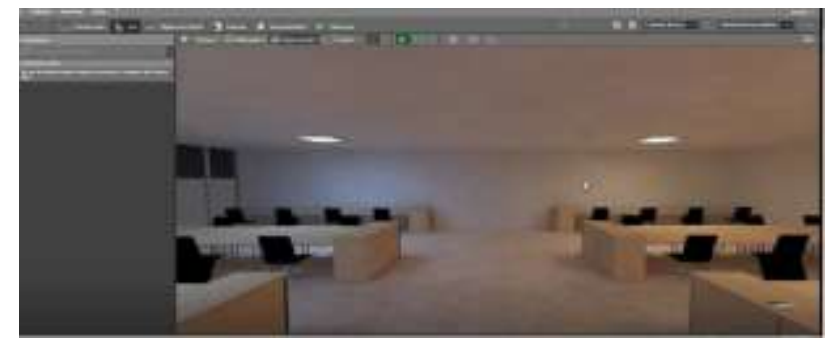

Figure 27 Data $3259^{\circ} \mathrm{K}$ Source: Dialux evo

As can be seen, the color of the light changes with respect to the color temperature of the LED lamp.

\section{Phase 8. Selection of the Light Color for different areas}

The colors that are warm are those that are from red to greenish yellow, which is less than 2,700 $\mathrm{K}$ and the cold ones are those that go from green to blue and are above $4,000 \mathrm{~K}$, the color of the light will be warmer or cooler depending on how close it is to red or blue, respectively.

The following table shows some recommendations for the light color required to obtain visual comfort:

\begin{tabular}{|c|c|c|}
\hline Area type & Needs & $\begin{array}{l}\text { light } \\
\text { color }\end{array}$ \\
\hline $\begin{array}{l}\text { Office, } \\
\text { classroom and } \\
\text { Mental Health } \\
\text { Centers }\end{array}$ & $\begin{array}{l}\text { Comfortable } \\
\text { atmosphere clear } \\
\text { lighting } \\
\text { concentration and do } \\
\text { not alter the senses with } \\
\text { stress or aggression }\end{array}$ & $\begin{array}{l}\text { Cold } \\
\text { light } \\
\text { color }\end{array}$ \\
\hline Restaurants & $\begin{array}{l}\text { Comfort, that is not too } \\
\text { intense and relaxing }\end{array}$ & $\begin{array}{c}\text { Warm } \\
\text { light color }\end{array}$ \\
\hline
\end{tabular}

Table 7 Light color for Classrooms and Restaurants Source: Self Made

\section{Results}

The results of the simulations are correct and coincide with those calculated by the lumens method, since the average level of illumination is above that required as determined by NOM025-STPS-2008, which in this case is $300 \mathrm{~lx}$ In addition, the tables and the blackboard are the most important areas, which have a good level of lighting so there is no need for modification.

The recommended color is cold white led light, a color that generates a perception of cleanliness, calm and spaciousness, ideal for academic activities. It is also advisable to use cool lights, between 4000 and $5000^{\circ} \mathrm{k}$, because they are the most appropriate to create a work environment that requires looking at short distances and paying close attention. A multipurpose classroom is situated in this context 


\section{Recommendations}

1. Despite the aforementioned benefits of using white light LEDs, it is preferable to use yellow LEDs. The reason is that white light radiates at $2500^{\circ} \mathrm{K}$ or more $60 \%$ of the colors visible to the human eye, among this range is the blue color like cell phones. The blue color affects the retina when unprotected eyes look at blue light in the form of a concentrated laser and also suppresses the generation of melatonin causing sleep disorders and as a consequence the quality of life of the patient. Using yellow light LEDs generates less range of blue light in the conditions evaluated in this work.

2. Using light colors for walls, ceilings and floors allows for better lighting due to the percentage of reflection, in addition light colors are relaxing. Dark colors do not help reflection and do not create peace. In the middle of these two extremes, are the gray colors generate feelings of discouragement, they should be used with caution.

3. Consider the psychology of color in the lighting design of the premises, because colors have a great impact on our health and our moods.

4. Avoid lighting systems that generate stroboscopic effects because they give the impression that rotating machines are stopped, which can cause accidents at work.

5. Avoid blue LEDs, because they contribute to damaging the eye macula, related to age with the appearance of cataracts and even blindness.

6. Avoid in lighting designs that the brightness falls directly on the eye. The risk of damage has a lot to do with the power of glitter. LEDs are bright sources of light, if you look at the end, a multicolored image persists on the retina that takes time to disappear.
7. Use endorsed LED lighting system software that comply with the NOM and consider lighting levels, color and light temperature.

\section{Conclusions}

Using the lumens method is of utmost importance to design efficient LED lighting systems, because the required lighting levels are guaranteed in lux according to the NOM specifications. Thus, low electricity consumption is achieved. A bad LED lighting design contributes negatively to visual health. An estimated 40 million Mexicans wear glasses.

Normally, in the designs of LED lighting systems, the only aim is to guarantee lighting levels and seek energy savings without considering: The colors of the area to be illuminated, the color temperature of the LEDs and the psychology of color. These contribute to a safe work environment, visual and psychological health and contribute to maximum visual performance, with minimal fatigue.

Poor lighting design leads to dizziness, stress, eye disorders such as sore and swollen eyelids, eyestrain, heaviness, tearing, redness, irritation, even distorted vision, myopia and astigmatism. such as difficulty falling asleep, falling asleep at inappropriate times, abnormal behaviors such as irritability, stress, poor concentration.

It is difficult to establish norms or fixed rules for the correct selection of the color temperature to have a certain effect, for this reason each project has to be treated in a different way due to the diversity of climates and tastes of human sensations such as heat or cold. , in addition to the various activities to be carried out in the areas to be illuminated.

The results obtained with the software simulations are correct and coincide with those calculated by the lumens method, since the average level of illumination is above that required as determined by NOM-025-STPS2008, which for this case was of $300 \mathrm{~lx}$. The classroom evaluated meets the required luxes, uses white LEDs, has light walls, floors and ceilings, and it is justified to change the white LEDs in the future to yellow LEDs of the same power and luminous flux. 


\section{References}

A. Martínez, C. (1979). psicología del color. plástica/dinámica.

Aguilar Vásquez, A. (2012). Iluminación artificial en viviendas. Universidad del Azuay,

Chapa Carreón, J. (2004). Manual de instalaciones de alumbrado $\mathrm{y}$ fotometría. México:

Duque, A., \& Vázquez, C. (2013). Implicaciones clínicas del uso del tamaño pupilar como indicador psicológico: una breve revisión. Clínica y salud, 97-100.

Fuentes, F. (2015). psicología del color. Obtenido de scribd: https://es.scribd.com

Garcia Noriega, R. E. (2021). Iluminación con tecnología led para la cancha de fútbol del corregimiento de Cornejo Norte de Santander.

Grados Portocarrero, E. R., Imán Coveñas, J., Melendres Córdova, C. D., Ocaña Huamán, A. R.,\& Ojeda Córdova, Y. M. (2021). Análisis económico de tecnologías de iluminación domiciliaria.

Graham, Helen. (2002). Curación con color. Ciudad de México: S.A. Grupo editorial Tomo

Heller, E. (2007). Psicologia del color. Munich: Gustavo Gili

Inc. DIAlux. (2020). DIAL. Obtenido de https://www.dial.de/en/dialux

Jean, D. F. (2019). Aplicación de la teoría de los colores de Goethe en la pintura contemporánea de Arequipa. Universidad Nacional de San Agustín de Arequipa, Arequipa.

Jiménez Arévalo, M. (2021). Ecotono. Un sistema de análisis alternativo. Atomósferas desde laluz y el color inmaterial.

Limusa. Ching, F. D. (2012). Diccionario visual de arquitectura. New Jersey: John Wiley y Sons

Mancera Fernandez, M., \& Mancera Ruiz, M. T. (2016). Seguridad y salud en el trabajo.

Colombia: Alfa omega.
Monteoliva, J., Villalba, A., \& Pattini, A. (2015). Temperaturas de color correlacionada de la luz natural: análisis dinámico en espacios interiores. Informes de la construcción, 67(540, 2-8 doi: 10.3989/ic.14.146.

NOM-025-STPS-2008. (2008). Diario oficial de la federación.

Posligua, N., \& Castro, M. (2015). Diseño de iluminacion con luminarias tipo led basado en el concepto eficiencia energetica y confort visual; implementacion estructural para pruebas. (Tesis de licenciatura). Universidad Politecnica Salesiana, Guayaquil.

Ruiz Esparza, G., Murieta Cummings, R., Mascott Pérez, Y., Aspe Bernal, M., Rámirez Reyes, R.,\& Poon Hung, C. (2015). Manual de iluminación vial. México: Obra independiente.

Secretaria del trabajo y previsión social. (30 de Diciembre de 2008). Diario oficial. Norma Oficial Mexicana NOM-025-STPS-2018. México, México.

Varley Helen \& Marshall Editions Ltd (1982). El gran libro del color. España. Editorial Barcelona Blume. 